\title{
The Effect of CEO and CFO Resignations on Going Concern Opinions
}

\author{
Joseph D. Beams ${ }^{1}$, Yun-Chia Yan $^{2}$, Wachira Boonyanet ${ }^{3} \&$ Pongprot Chatraphorn $^{3}$ \\ ${ }^{1}$ Department of Accounting, University of New Orleans, New Orleans, USA \\ ${ }^{2}$ School of Accountancy, University of Texas Rio Grande Valley, Brownsville, USA \\ ${ }^{3}$ Department of Accounting, Chulalongkorn University, Bangkok, Thailand \\ Correspondence: Yun-Chia Yan, School of Accountancy, University of Texas Rio Grande Valley, Brownsville, USA
}

Received: August 29, 2016

Accepted: September 24, 2016

Online Published: October 4, 2016

doi:10.5430/afr.v5n4p76

URL: http://dx.doi.org/10.5430/afr.v5n4p76

\begin{abstract}
Anecdotal evidence suggests that the resignation of a top executive increases a firm's likelihood of failure. When auditors perceive an increased likelihood of failure, a going concern modified audit opinion is issued. This study tests the relationship between top management resignations and the issuance of going concern audit opinions. The study uses financially distressed firms in the United States from 2008-2010 and a logistic regression model to test the relationship. The findings show a positive relationship between CFO resignations and firms receiving a going concern audit opinion even after controlling for other predictors of a going concern audit opinion. However, no significant relationship is found between CEO resignations and receiving a going concern audit opinion. Firm size, cash flow from operations, stock return, and investments all had a significant relationship with going concern opinions.
\end{abstract}

Keywords: Going Concern, CEO, CFO, Resignation

\section{Introduction}

The resignation of a top executive can cause concern among investors and creditors of a company. The resignation of a CEO or CFO can be for many reasons, some of which provide additional information about the value of the company (e.g. Beatty et al, 1987; Mian, 2001; Dedman and Lin, 2002). The resignation of a top executive can signal hard times ahead for the company. Does the resignation increases the likelihood of the company receiving a going concern opinion? This could be because the company lacks experienced leadership or because the resignation of top executives could be a sign that those with the greatest information about the company do not like its future.

Corporations use a variety of measures designed to align the interests of top executives and the stockholders so that executives will make decisions that benefit stockholders. Some of the methods used to align these interests include performance based bonuses, stock options, and stock appreciation rights. However, there are still situations which an agent may personally benefit more by doing something that is not in the corporation's best interest.

The news media has publicized many stories of corporate executives using insider information to gain an advantage in stock trading. This use of insider information is illegal. However, this is not the only use of insider information. If a top executive sees that his company is going downhill or has a significant negative event forthcoming, the executive may choose to resign from the company and find a new job. This individual has benefited from the non-public information; however, he has not broken the law.

Recognizing when a company is declining can be valuable to an investor or an executive. The investor may be able to sell his stock and make a profit or avoid a loss, or sell the stock short and make an abnormal gain before others recognize the problems. An executive who sees hard times coming for his company can disassociate himself with the company by resigning and finding a new company. Top executives will always know more about a company than outside investors and they will have the information earlier.

Financial statements and the audit report are not published until several months after a corporation's fiscal year ends. Top executives within the company already know how the company is doing and they will have additional non-public information long before the financial statements and audit report are issued. Do top executives consider this information when considering a career move and, if so, do their actions increase the likelihood of the company receiving a going concern audit opinion? 
This paper investigates whether the resignation of a CEO or CFO is associated with an increased likelihood of a company receiving a going concern opinion. The evidence clearly indicates that when a CFO resigns, the likelihood of the company receiving a going concern audit opinion is increased.

The remainder of this paper is organized as follows. Section 2 provides a review of prior literature and the development of testable hypotheses. Section 3 describes the sample and the methodology used to test the hypotheses. The results of the tests are presented in section 4. Section 5 is a discussion of the results and section 6 provides a conclusion.

\section{Prior Literature and Hypothesis Development}

This study looks at the relationship between top management resignations and their firms' receiving going concern audit opinions. If a manager believes the firm's prospects are declining, he/she may resign prior to the public finding out that the firm is going downhill. By doing so, the manager's future job prospects may be better.

\subsection{Top Executive Resignation and Employment Prospects}

Prior studies have looked at the factors associated with management turnover. Some studies look at restatements of financial statements, some look at decreases in stock price, and others look at poor firm performance.

When top management is not performing as expected, the board of directors may choose to replace them (Desai et al. 2006, Farrell and Whidbee 2003). When new executives come in they are more likely to manage earnings down in the year of the change and up in the following year (Pourciau, 1993; Godfrey et al., 2003) Menon and Williams (2008) find that CEO and CFO turnover is higher after a firm's auditors resign. Desai et al. (2006) find that top management turnover is also higher after an earnings restatement.

When a manager is removed for poor performance, his marketability for a new job is diminished (Desai et al. 2006). Fee and Hadlock (2004) find that turnover of non-CEO executives is affected by CEO displacement and that the new jobs acquired by the dismissed managers are subordinate to their previous jobs. Gilson(1989) finds that executives of financially distressed companies are not hired by another company for at least three years following their departure and suffer enormous personal costs.

This provides an incentive for top executives to resign before the deterioration of the company is fully reflected in the financial statements and the public is aware of the problems. Once the problems appear in the financial statements, the top executive may be dismissed, and at that point his/her future employment prospects are seriously decreased. While there are numerous reasons for executives to resign, a resignation by a top executive may be a sign that hard times are ahead for the company.

Feldmann et al. (2009) find that audit risk is increased for firms that have a prior year financial restatement. The authors measure audit risk by an increase in audit fees. The study shows that when a CFO turnover is associated with the financial restatement, it helps to mitigate the increase in audit fees, but a CEO turnover does not have a similar effect.

\subsection{Factors Affecting Going Concern Opinions}

An auditor's going concern opinion is intended to notify the public that a company is experiencing financial difficulty and may have a higher likelihood of bankruptcy. Prior studies have looked at factors that are associated with auditors' going concern opinions.

Chen and Church (1996) find that there is less market surprise to bankruptcy filings when a firm has received a going concern audit opinion. Beams et al. (2013) find that firms in which a top executive resigns have a higher likelihood of declaring bankruptcy over the next several years. Carey et al. (2008) test Australian companies and finds firms are more likely to switch auditors if they receive a going concern audit opinion but do not find that receiving a going concern audit opinion leads to a greater likelihood of bankruptcy than already exists for the distressed firms. Geiger et al. (2005) find that auditors were more likely to issue going concern opinions after December 2001 than previously. The authors attribute this difference to the change in attitudes following major corporate scandals and the passage of the Sarbanes Oxley Act.

The departure of a top executive has been associated with a decrease in stock price. Beatty et al. (1987) find that the announcement of a CEO change is related to a decrease in a firm's market value and Mian (2001) documents a negative market reaction to CFO turnover. Dedman and Lin (2002) find a negative stock price reaction to the announcement that a top executive is leaving, especially if the executive leaves for another job. These studies indicate that a resignation by top management is a negative sign for the company and therefore may be considered by auditors in the assessment of going concern opinions. 
The research on executive resignations and going concern audit opinions leads to our hypotheses that CEO and CFO resignations will have a significant positive relationship with the likelihood of receiving a going concern audit opinion. We test this question with the following two hypotheses:

$\mathbf{H}_{1}$ : A company is more likely to receive a going concern audit opinion after a resignation of its CEO.

$\mathbf{H}_{2}$ : A company is more likely to receive a going concern audit opinion after a resignation of its CFO.

In addition to these variables, we include control variables from prior going concern research. Past research generally indicates that the probability of receiving a going concern opinion is negatively associated with firm size ( $\operatorname{LnTA})$ (Carcello and Neal 2000; Behn et al. 2001; Geiger et al. 2005; Knechel and Vanstraelen 2007; Feldmann and Read 2010). Receiving a going concern opinion is found to be positively associated with the company's degree of financial distress as measured by Z-score (Z) (Carcello and Neal 2000). Z-score is a combination of return on assets, financial leverage and liquidity. Going concern opinions are found to be negatively associated with cash flow from operating activities deflated by total assets or total liabilities (CF/TA) (Chen and Church 1992; Behn et al. 2001). Size of auditing firm (Big4) has been found to have a positive relationship to going concern audit opinion (Behn et al. 2001). However, other researchers have found no significant relationship between Big $\mathrm{N}$ auditor and going concern opinions (Geiger et al. 2005; Feldmann and Read 2010; Knechel and Vanstraelen 2007).

Four control variables from the Defond et al. (2002) model are also included in the current model. The one year stock market return (RETURN) is expected to be negatively associated with the likelihood of receiving a going concern opinion. Higher volatility (VOLATILITY) is expected to be positively associated with receiving a going concern opinion. Leverage (LEV), defined as total liabilities divided by total assets, is expected to be positively associated with receiving a going concern audit opinion. A control variable for INVESTMENTS, defined as short and long term investment securities (including cash and cash equivalents) deflated by total assets (TA), is expected to have a negative relationship to receiving a going concern audit opinion.

Earnings restatements have been found to be associated with an increased likelihood of management turnover (Desai et al. 2006, Feldmann et al. 2009). A control variable for earnings restatements is also included in our model. Earnings restatements are expected to be positively associated with receiving a going concern audit opinion. Control variables are also added to control for current year industry sic codes as defined in Krishnan (2005). Additionally, since the data set spans multiple years, we control for year.

\section{Sample and Methodology}

We test the impact of top executive resignations on firm audit opinions for firms in the United States for the years 2008-2010. We draw the sample variables from the Audit Analytics database and Compustat database. Any firms that are not in both databases are removed. Firms in the financial industries are removed because they have different reporting requirements. As with prior going concern research, we restrict our analysis to initial going concern opinion firms, that is, we removed companies that had a prior year going concern opinion, since they are more likely to receive a going concern opinion in the current year.

Following prior going concern research, we limit our sample to financially distressed firms and define financially distressed firms as used in DeFond et al. (2002). This definition identifies a firm as financially distressed if it has negative earnings or negative operating cash flows. This provides a useable sample of 4,240 firms. We winsorized the continuous variables in the model at the $1 \%$ and $99 \%$ percentiles.

In the initial analysis, the sample is separated into two groups based on whether the firms received a going concern opinion. The means from the variables in the going concern group are compared with the variables in the non-going concern group. T-tests are conducted on the variables to determine if there are significant differences between the independent variables in each group.

\subsection{Regression Models}

To determine if firms that had a top executive resign are more likely to receive a going concern opinion, separate regressions are run to test the effects of a resigned CEO and a resigned CFO. Logistic regression models are used to test the hypotheses. The audit opinion (going concern or not going concern) is used as the dependent variable. In each model this variable is given a value of " 1 " if the firm received a going concern audit opinion and " 0 " if the firm did not receive a going concern opinion in that year.

The first logistic regression tests the relationship between a CEO resignation and a firm receiving a going concern opinion. The independent variable for the CEO resigning and other independent variables identified from prior literature are tested for their effect on the going concern opinion. The variable for a CEO resigning receives a value 
of "1" if the CEO resigned during the year and " 0 " if the CEO did not resign. The following model is used to test this hypothesis.

Model 1: GC $(1,0)=\beta_{0}+\beta_{1} *$ ResignedCEO $+\beta_{2} *$ LNTA $+\beta_{3} * C F / T A+\beta_{4} * Z+\beta_{5} *$ BIG $4+\beta_{6} *$ VOLATILITY $+\beta_{7} *$ RETURN $+\beta_{8} *$ INVESTMENTS $+\beta_{9} *$ LEV $+\beta_{10} *$ RESTATEMENT $+\beta_{11} *$ YEAR09 $+\beta_{12} *$ YEAR $10+\beta_{13} *$ IND $+\varepsilon$

where:

$G C$

ResignedCEO

LNTA

$C F / T A$

$Z$

BIG4

VOLATILITY

RETURN

INVESTMENTS

$L E V$

RESTATEMENT

YEARO9

YEAR10

IND
= Going concern, 1 if audit opinion is going concern, 0 otherwise;

$=$ Indicator variable that takes a value of 1 if the CEO resign in the year, otherwise zero;

$=$ Natural log of total assets (in millions of dollars);

= Net cash flow from operating activities scaled by total assets;

= Z-score from Zmijewski's (1984) model;

$=$ Indicator variable that takes a value of 1 if audited by a Big 4 accounting firm, otherwise zero;

$=$ Standard deviation of annual stock returns in recent three years;

$=$ One-year common stock return;

$=$ Short and long term investment securities (including cash and cash equivalents) deflated by total assets (TA);

$=$ Total liabilities over total assets;

$=1$ if firm restated its current financial statement, else 0 ;

$=1$ if year 2009, else 0 ;

$=1$ if year 2010, else 0 ;

$=$ Industry dummy variables as defined in Krishnan (2005).

The second hypothesis tests the relationship between the CFO resigning and the company receiving a going concern audit opinion. The following model is used to test this hypothesis:

Model 2: $G C(1,0)=\beta_{0}+\beta_{1} *$ ResignedCFO $+\beta_{2}{ }^{*} L N T A+\beta_{3}{ }^{*} C F / T A+\beta_{4}{ }^{*} Z+\beta_{5}{ }^{*}$ BIG4 $+\beta_{6}{ }^{*}$ VOLATILITY $+\beta_{7}{ }^{*}$ RETURN $+\beta_{8} *$ INVESTMENTS $+\beta_{9} *$ LEV $+\beta_{10} *$ RESTATEMENT $+\beta_{11} *$ YEAR09 $+\beta_{12} *$ YEAR $10+\beta_{13} *$ IND $+\varepsilon$

All variables in this model are defined as in the previous model except that ResignedCFO is defined as follows:

ResignedCFO = Indicator variable that takes a value of 1 if the CFO resigns in the year, otherwise zero.

Model 3 is similar to the first two but includes both ResignedCEO and ResignedCFO in the same model.

Model 3: $G C(1,0)=\beta_{0}+\beta_{1} *$ ResignedCEO $+\beta_{2} *$ Resigned $C F O+\beta_{3} * L N T A+\beta_{4} * C F / T A+\beta_{5} * Z+\beta_{6} * B I G 4+\beta_{7} *$ VOLATILITY $+\beta_{8} *$ RETURN $+\beta_{9} *$ INVESTMENTS $+\beta_{10} *$ LEV $+\beta_{11} *$ RESTATEMENT $+\beta_{12} *$ YEAR09 $+\beta_{13} *$ YEARIO $+\beta_{14} * I N D+\varepsilon$

\section{Results}

Table 1 shows descriptive statistics for the sample firms and for the control variables. The mean (median) total assets for the sample firms are $\$ 1,586,217,000(\$ 95,754,000)$. The mean is much higher than the median due to the presence of some very large firms in the sample. The mean (median) cash flow for the sample firms is $\$ 103,057,000$ $(-\$ 398,000)$. The mean (median) net income for the sample firms is $-\$ 74,047,000(-\$ 10,722,000)$. It is not surprising that the median cash flow and net income are negative since these are all distressed firms. 
Table 1. Descriptive Statistics of Sample Firms ( $=4,240)$

\begin{tabular}{lccccc}
\hline \multicolumn{1}{c}{ Variable } & Mean & Min & Median & Max & Std. Dev. \\
\hline Total Assets(\$M) & 1586.217 & 0.099 & 95.754 & 53779.000 & 6467.017 \\
Net Income(\$M) & -74.047 & -1619.000 & -10.722 & 290.000 & 232.403 \\
Cash Flows(\$M) & 103.057 & -191.439 & -0.398 & 4996.240 & 571.205 \\
LNTA & 4.544 & -2.526 & 4.527 & 10.166 & 2.435 \\
CF/TA & -0.211 & -5.280 & -0.016 & 0.301 & 0.721 \\
Z & 3.428 & -3.990 & -1.021 & 187.173 & 22.693 \\
Big4 & 0.530 & 0.000 & 1.000 & 1.000 & 0.499 \\
VOLATILITY & 17.293 & 0.055 & 0.562 & 1076.839 & 116.642 \\
RETURN & & & & & \\
INVESTMENTS & 1.984 & -0.953 & -0.123 & 116.667 & 13.106 \\
LEV & 0.211 & 0.000 & 0.127 & 0.968 & 0.231 \\
& & & & & \\
& 0.981 & 0.012 & 0.510 & 22.343 & 2.638 \\
& & & & & \\
\hline
\end{tabular}

Table 2 panel A shows the total number of going concern opinions for the sample firms and the number of firms in which a CEO or CFO resigned. Going concern opinions are issued to $439(10.36 \%)$ of the 4,240 sample firms. A total of 342 CEOs resigned which is $8.07 \%$ of the sample firms and similarly there are 362 CFO resignations, or $8.54 \%$ of the sample.

Table 2 panel B separates firms that received a going concern audit opinion by whether they also had their CEO resign. The table shows that of the firms that had a CEO resign during the year, 13.16\% (45/342) received a going concern opinion. For firms that did not have a CEO resign during the year, 10.11\% (394/3504) received a going concern opinion. Table 2 panel $\mathrm{C}$ shows that this difference is much greater for the CFO resign group. If a CFO resigns, the likelihood of receiving a going concern opinion is $16.3 \%$ (59/362) whereas if the CFO does not resign, the likelihood of receiving a going concern opinion is only $9.8 \%$ (380/3878). 
Table 2. Comparison of Going Concern Firms to Non-Going Concern Firms $(\mathrm{N}=4,240)$

Panel A: Count and Percentages for Going Concern and Variables of Interest

\begin{tabular}{lcc}
\hline & N & \% \\
\hline Going Concern Opinion & 439 & $10.35 \%$ \\
Resigned CEO & 342 & $8.07 \%$ \\
Resigned CFO & 362 & $8.54 \%$ \\
\hline
\end{tabular}

Panel B - CEO Resignation and Going Concern Audit Opinion

\begin{tabular}{lccc}
\hline & Going Concern & NON-Going Concern & Observations \\
\hline ResignedCEO & $45(13.16 \%)$ & $297(86.84 \%)$ & 342 \\
NON-ResignedCEO & $394(10.11 \%)$ & $3504(89.89 \%)$ & 3898 \\
\hline
\end{tabular}

Panel C - CFO Resignation and Going Concern Audit Opinion

\begin{tabular}{lccc}
\hline & Going Concern & NON-Going Concern & Observations \\
\hline ResignedCFO & $59(16.30 \%)$ & $303(83.70 \%)$ & 362 \\
NON-ResignedCFO & $380(9.80 \%)$ & $3498(90.20 \%)$ & 3878 \\
\hline
\end{tabular}

The study next compares the means of the variables by group (going concern opinion group or non-going concern opinion group). Table 3 compares the independent variables across the groups and tests for differences in the variables. Of the sample firms, 439 received a going concern opinion. The other 3,801 firms did not receive a going concern audit opinion.

The results show a CEO resigned in $10.3 \%$ of the 439 firms that received a going concern audit opinion. Only $7.8 \%$ of 3,801 firms that did not receive a going concern had a CEO resign. This difference is not statistically significant. By contrast, a CFO resigned in $13.4 \%$ of the firms that received a going concern opinion but a CFO resigned in only $8.0 \%$ of the firms that did not receive a going concern opinion. This difference is significant at $\mathrm{p}=.001$.

There are also significant differences between the going concern group and the non-going concern group for all of the control variables except volatility and restatements. The log of total assets and cash flow variable are significantly lower $(\mathrm{p}<.001)$ for the going concern group. This is also consistent with expectations based on prior studies. The difference in Z-score is also significant at $\mathrm{p}<.006$.

For the firms that received a going concern audit opinion, $42.8 \%$ were audited by a Big 4 accounting firm. For the group that did not receive a going concern audit opinion, $54.6 \%$ were audited by a Big 4 accounting firm. This difference is significant at the $\mathrm{p}<.001$ level. This result was counter to what was expected. Prior research has been mixed on whether Big 4 auditors are more likely to issue a going concern audit opinion. Care should be taken in interpreting the results of these variables in isolation. These results suggest that without controlling for other variables, non big 4 auditors issued a higher percentage of going concern audit opinions for these companies. However, these simple comparisons of means do not control for other factors like differences in the size or financial health of the clientele of Big 4 versus non-Big 4 accounting firms. It may be the case that the Big 4 accounting firms are able to identify other strengths that in some cases mitigate the need for a going concern opinion. It may also be that non-Big 4 firms may be quick to issue a going concern opinion. 
Table 3. Comparison of Going Concern Opinion Firms with Non-Going Concern Opinion Firms

\begin{tabular}{lccccc}
\hline Variable & $\begin{array}{c}\text { Going } \\
\text { Concern } \\
(\text { Means }) \\
(\mathbf{n = 4 3 9 )}\end{array}$ & $\begin{array}{c}\text { Non-Going } \\
\text { Concern } \\
\text { Means } \\
(\mathbf{n = 3 8 0 1 )}\end{array}$ & $\begin{array}{c}\text { Difference in } \\
\text { means }\end{array}$ & t-value & $\begin{array}{c}\text { p-value } \\
\text { (2-tailed) }\end{array}$ \\
\hline ResignedCEO & .103 & .078 & .024 & 1.610 & .108 \\
ResignedCFO & .134 & .080 & .055 & 3.240 & $.001^{* * *}$ \\
LnTA & 3.873 & 4.621 & -.748 & 5.716 & $.000^{* * *}$ \\
CF/TA & -.420 & -.187 & -.232 & 4.897 & $.000^{* * *}$ \\
Z & 6.631 & 3.058 & 3.573 & 2.73 & $.006^{* * *}$ \\
Big4 & .428 & .546 & -.118 & 4.720 & $.000^{* * *}$ \\
Volatility & 12.761 & 17.817 & -5.056 & 1.014 & .311 \\
Return & .773 & 2.124 & -1.351 & 3.477 & $.011^{* *}$ \\
Investments & .186 & .214 & -.028 & 2.396 & $.017^{* *}$ \\
Leverage & 1.247 & .950 & .297 & 2.051 & $.041^{* *}$ \\
Restatement & .050 & .039 & .011 & 1.002 & .317 \\
\hline
\end{tabular}

$* * *, * *, *$ Denote significance at the $0.01,0.05$, and 0.10 levels, respectively.

The variables are defined as follows:

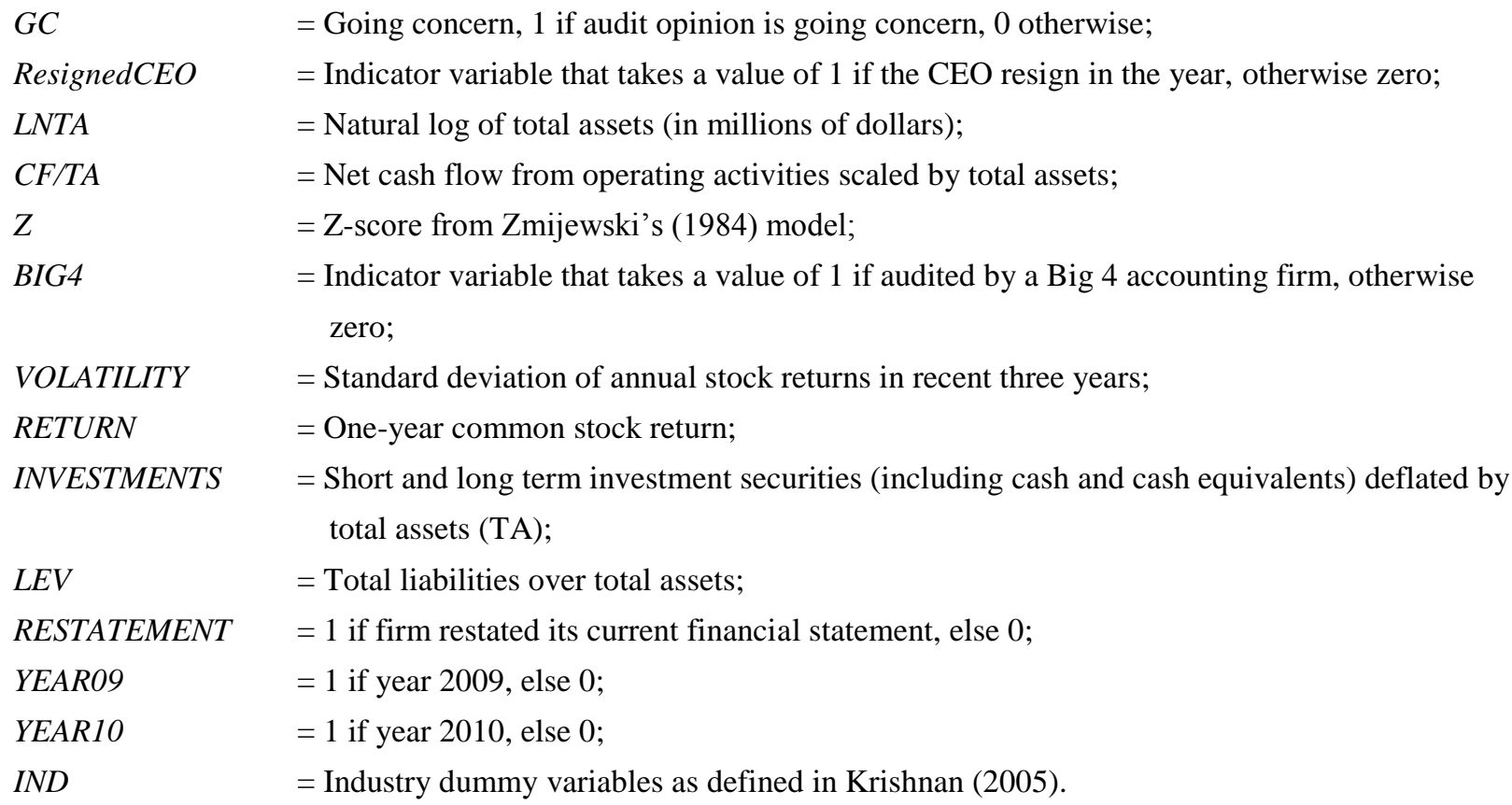

The previous analysis compares the means of the groups in isolation. The main analysis uses logistic regression models to compare the effects of the variables in combination with each other. Table 4 shows the result of the regression model used to test $\mathbf{H}_{1}$, that a company is more likely to receive a going concern opinion if its CEO resigns during the year. The variable of interest is resigned CEO. Table 4 shows that resigned CEO has the expected sign but is not significant at $\mathrm{p}=.106$. The variables for size and cash flow, both have the expected sign and are significant at the $\mathrm{p}=.001$ and $\mathrm{p}<.001$, respectively. The variables for return and investments also have the expected sign and are significant at $\mathrm{p}=.024$ and $\mathrm{p}<.001$, respectively. The variables for Z-score, Big 4 accounting firm, volatility, leverage, and restatement are not significant. The significance of the control variable for year indicates that there was a greater likelihood of receiving a going concern opinion in the 2010 sample year. 
Table 4. Regression Results for CEO Resignation and Going Concern Audit Opinion ( $N=4,240)$

Model:

$$
\begin{aligned}
G C= & \beta_{0}+\beta_{1}^{*} \text { ResignedCEO }+\beta_{2} * \text { LNTA }+\beta_{3}^{*} \text { CF/TA }+\beta_{4} * Z+\beta_{5} * \text { BIG4 } \\
& +\beta_{6} * \text { VOLATILITY }+\beta_{7} * \text { RETURN }+\beta_{8} * \text { INVESTMENTS }+\beta_{9} * \text { LEV } \\
& +\beta_{10} * \text { RESTATEMENT }+\beta_{11} * \text { YEARO9 }+\beta_{12} * \text { YEARIO }+\beta_{13} * \text { IND }+\varepsilon
\end{aligned}
$$

\begin{tabular}{|c|c|c|c|}
\hline Variables & Predicted Sign & Coefficient & p-value \\
\hline Intercept & $?$ & -1.257 & $0.005 * * *$ \\
\hline ResignedCEO & + & 0.218 & 0.106 \\
\hline LNTA & - & -0.114 & $0.001 * * *$ \\
\hline$C F / T A$ & - & -0.395 & $<0.001 * * *$ \\
\hline$Z$ & + & 0.001 & 0.492 \\
\hline BIG4 & + & -0.127 & 0.340 \\
\hline VOLATILITY & + & -0.001 & 0.296 \\
\hline RETURN & - & -0.014 & $0.024 * *$ \\
\hline INVESTMENTS & - & -1.315 & $<0.001 * * *$ \\
\hline$L E V$ & + & -0.085 & 0.136 \\
\hline RESTATEMENT & + & 0.166 & 0.250 \\
\hline YEAR09 & $?$ & -0.202 & $0.088^{*}$ \\
\hline YEARIO & $?$ & -0.765 & $<0.001 * * *$ \\
\hline$I N D$ & $?$ & Contrc & lled \\
\hline Model Chi-square & & 130.64 & \\
\hline $\mathrm{R}^{2}$ & & $6.24 \%$ & \\
\hline $\mathrm{N}$ & & 4,240 & \\
\hline
\end{tabular}

$* * *, * *, *$ Denote significance at the $0.01,0.05$, and 0.10 levels, respectively.

$\mathrm{P}$-values are one-tailed if direction is predicted, otherwise two-tailed.

The variables are defined as follows:

$G C=$ Going concern, 1 if audit opinion is going concern, 0 otherwise;

ResignedCEO = Indicator variable that takes a value of 1 if the CEO resign in the year, otherwise zero;

LNTA = Natural log of total assets (in millions of dollars);

CF/TA $\quad=$ Net cash flow from operating activities scaled by total assets;

$Z$

= Z-score from Zmijewski's (1984) model;

BIG4 = Indicator variable that takes a value of 1 if audited by a Big 4 accounting firm, otherwise zero;

VOLATILITY = Standard deviation of annual stock returns in recent three years;

RETURN = One-year common stock return;

INVESTMENTS = Short and long term investment securities (including cash and cash equivalents) deflated by total assets (TA);

$L E V \quad=$ Total liabilities over total assets;

RESTATEMENT $=1$ if firm restated its current financial statement, else 0;

YEARO9 $\quad=1$ if year 2009, else 0;

YEAR10 = 1 if year 2010, else 0;

IND = Industry dummy variables as defined in Krishnan (2005). 
Table 5 tests $\mathbf{H}_{2}$, that a company is more likely to receive a going concern opinion if its CFO resigns during the year. The variable for resigned CFO is in the expected direction and significant at the $\mathrm{p}=.001$ level which indicates that this variable has explanatory power in addition to the other variables in the model. The results for the other variables are similar to the previous model. The variables for total assets, cash flow, return, and investments all have the expected sign and are significant. Z-score, Big 4 accounting firm, volatility, leverage, and restatement are not significant.

Table 5. Regression Results for CFO Resignation and Going Concern Audit Opinion $(\mathrm{N}=4,240)$

Model:

$$
\begin{aligned}
G C= & \beta_{0}+\beta_{1} * \text { ResignedCFO }+\beta_{2} * \text { LNTA }+\beta_{3}^{*} \text { CF } / T A+\beta_{4} * Z+\beta_{5} * \text { BIG } \\
& +\beta_{6} * \text { VOLATILITY }+\beta_{7} * \text { RETURN }+\beta_{8} * \text { INVESTMENTS }+\beta_{9} * \text { LEV } \\
& +\beta_{10} * \text { RESTATEMENT }+\beta_{11} * \text { YEARO }+\beta_{12} * \text { YEARIO }+\beta_{13} * \text { IND }+\varepsilon
\end{aligned}
$$

\begin{tabular}{|c|c|c|c|}
\hline Variables & Predicted Sign & Coefficient & p-value \\
\hline Intercept & $?$ & -1.267 & $0.005 * * *$ \\
\hline ResignedCFO & + & 0.509 & $0.001 * * *$ \\
\hline LNTA & - & -0.115 & $0.001 * * *$ \\
\hline$C F / T A$ & - & -0.392 & $<0.001 * * *$ \\
\hline Z & + & 0.001 & 0.482 \\
\hline BIG4 & + & -0.120 & 0.367 \\
\hline VOLATILITY & + & -0.001 & 0.285 \\
\hline RETURN & - & -0.013 & $0.025 * *$ \\
\hline INVESTMENTS & - & -1.282 & $<0.001 * * *$ \\
\hline$L E V$ & + & -0.086 & 0.134 \\
\hline RESTATEMENT & + & 0.167 & 0.248 \\
\hline YEAR09 & $?$ & -0.186 & 0.117 \\
\hline YEARIO & $?$ & -0.757 & $<0.001 * * *$ \\
\hline$I N D$ & $?$ & Contrc & lled \\
\hline Model Chi-square & & 138.92 & \\
\hline $\mathrm{R}^{2}$ & & $6.63 \%$ & \\
\hline $\mathrm{N}$ & & 4,240 & \\
\hline
\end{tabular}

$* * *, * *, *$ Denote significance at the $0.01,0.05$, and 0.10 levels, respectively.

$\mathrm{P}$-values are one-tailed if direction is predicted, otherwise two-tailed.

The variables are defined as follows:

GC= Going concern, 1 if audit opinion is going concern, 0 otherwise;

ResignedCFO = Indicator variable that takes a value of 1 if the CFO resign in the year, otherwise zero;

LNTA = Natural log of total assets (in millions of dollars);

$C F / T A=$ Net cash flow from operating activities scaled by total assets;

Z $\quad$ Z Z-score from Zmijewski's (1984) model;

BIG4 = Indicator variable that takes a value of 1 if audited by a Big 4 accounting firm, otherwise zero;

VOLATILITY = Standard deviation of annual stock returns in recent three years;

RETURN = One-year common stock return;

INVESTMENTS = Short and long term investment securities (including cash and cash equivalents) deflated by total assets (TA); 
LEV = Total liabilities over total assets;

RESTATEMENT = 1 if firm restated its current financial statement, else 0;

YEARO9 = 1 if year 2009, else 0;

YEAR10 = 1 if year 2010, else 0;

IND = Industry dummy variables as defined in Krishnan (2005).

The final model includes variables for resigned CEO and resigned CFO as well as the other independent variables. Table 6 shows the results for this model. The variable for resigned CEO has the expected sign but is still not significant. Resigned CFO has the expected sign and is significant at $\mathrm{p}<.001$. Similar to the previous models, the variables for total assets, return, and investments all had the expected sign and were significant. Z-score, Big 4 accounting firm, volatility, leverage, and restatement were again not significant.

Resigned CEO was not significant in the model with resigned CFO or in the model without resigned CFO. However, resigned $\mathrm{CFO}$ has a strong significant positive relationship to receiving a going concern audit opinion whether resigned $\mathrm{CEO}$ is in the model or not. These results suggest that a CFO resigning is a much greater indication that a company will receive a going concern audit opinion than a CEO resigning.

Table 6. Regression Results for CEO and CFO Resignation and Going Concern Audit Opinion $(\mathrm{N}=4,240)$

Model:

$$
\begin{aligned}
G C= & \beta_{0}+\beta_{1} * \text { ResignedCEO }+\beta_{2} * \text { ResignedCFO }+\beta_{3}^{*} \text { LNTA }+\beta_{4}^{*} \text { CF } / T A+\beta_{5} * Z \\
& +\beta_{6}^{*} \text { BIG }+\beta_{7}^{*} \text { VOLATILITY }+\beta_{8}^{*} \text { RETURN }+\beta_{9} * \text { INVESTMENTS } \\
& +\beta_{10} * \text { LEV }+\beta_{11} * \text { RESTATEMENT }+\beta_{12} * \text { YEARO9 }+\beta_{13} * \text { YEARIO } \\
& +\beta_{14} * I N D+\varepsilon
\end{aligned}
$$

\begin{tabular}{|c|c|c|c|}
\hline Variables & Predicted Sign & Coefficient & p-value \\
\hline Intercept & $?$ & -1.274 & $0.004 * * *$ \\
\hline ResignedCEO & + & 0.137 & 0.221 \\
\hline ResignedCFO & + & 0.490 & $0.001 * * *$ \\
\hline LNTA & - & -0.115 & $0.001 * * *$ \\
\hline$C F / T A$ & - & -0.389 & $<0.001 * * *$ \\
\hline$Z$ & + & 0.001 & 0.482 \\
\hline BIG4 & + & -0.122 & 0.362 \\
\hline VOLATILITY & + & -0.001 & 0.283 \\
\hline$R E T U R N$ & - & -0.014 & $0.024 * *$ \\
\hline INVESTMENTS & - & -1.285 & $<0.001 * * *$ \\
\hline$L E V$ & + & -0.085 & 0.138 \\
\hline RESTATEMENT & + & 0.157 & 0.262 \\
\hline YEAR09 & $?$ & -0.186 & 0.119 \\
\hline$Y E A R 10$ & $?$ & -0.753 & $<0.001 * * *$ \\
\hline$I N D$ & $?$ & Contro & lled \\
\hline Model Chi-square & \multicolumn{3}{|c|}{139.49} \\
\hline $\mathrm{R}^{2}$ & \multicolumn{3}{|c|}{$6.66 \%$} \\
\hline $\mathrm{N}$ & \multicolumn{3}{|c|}{4,240} \\
\hline
\end{tabular}

$* * *, * *, *$ Denote significance at the $0.01,0.05$, and 0.10 levels, respectively.

$\mathrm{P}$-values are one-tailed if direction is predicted, otherwise two-tailed. 
The variables are defined as follows:

$G C$

ResignedCEO

ResignedCFO

LNTA

CF/TA

$Z$

BIG4

VOLATILITY

RETURN

INVESTMENTS

$L E V$

RESTATEMENT

YEARO9

YEARIO

IND

\section{Discussion}

$=$ Going concern, 1 if audit opinion is going concern, 0 otherwise;

$=$ Indicator variable that takes a value of 1 if the CEO resign in the year, otherwise zero;

$=$ Indicator variable that takes a value of 1 if the CFO resign in the year, otherwise zero;

$=$ Natural log of total assets (in millions of dollars);

= Net cash flow from operating activities scaled by total assets;

= Z-score from Zmijewski's (1984) model;

$=$ Indicator variable that takes a value of 1 if audited by a Big 4 accounting firm, otherwise zero;

$=$ Standard deviation of annual stock returns in recent three years;

= One-year common stock return;

= Short and long term investment securities (including cash and cash equivalents) deflated by total assets (TA);

$=$ Total liabilities over total assets;

$=1$ if firm restated its current financial statement, else 0 ;

$=1$ if year 2009, else 0 ;

$=1$ if year 2010, else 0;

$=$ Industry dummy variables as defined in Krishnan (2005).

These results indicate that when a CFO resigns during the year, a firm has a higher likelihood of receiving a going concern opinion on its audit report from the external auditors. This result holds true even after controlling for other predictors of a going concern opinion that have been found in previous studies. There are several forces that may be contributing to this occurrence. One is that the CFO is so essential to the continuing success of the company that when one leaves, it will have a disabling effect on the company, making it more likely to fail. A second explanation is that the CFO recognizes the company is in trouble and foresees the possibility of a going concern audit opinion. The CFO decides to resign and find a new job before getting the stigma attached to a failing company. A third explanation is that the audit firm either intentionally or unintentionally sees the resignation of a CFO as a sign that the company is in distress or is hiding something and incorporates this perception into the assessment of the audit opinion. The auditors may be concerned that the CFO knows something that they do not. Previous studies have found that if auditors perceive management lacks integrity, the audit risk is increased (Beaulieu 2001, Kizirian et al.2005).

The results in table 3 suggests that Big 4 accounting firms may have an unexpected effect on a going concern audit opinion; however, after controlling for the other variables in the model, the variable for Big 4 accounting firm does not have a significant relationship to the going concern opinion. Because this study did not address how many firms from each group eventually filed for bankruptcy, there is no assessment of the accuracy of the going concern opinion for each group. Knechel and Vanstraelen (2007) investigate audit quality of going concern opinions. They do not find Big 6 accounting firms more likely to issue going concern opinions. However, they find that non-Big 6 accounting firms are more likely to issue going concern opinions to companies that do not go bankrupt.

\section{Conclusion}

This study identifies and documents a higher likelihood of receiving a going concern opinion for companies that have a CFO resign during the year. During the sample period, $10.4 \%$ of the sample firms received going concern audit opinions. A company that had a CFO resign had a $16.3 \%$ chance of receiving a going concern audit opinion, whereas a company that did not have a CFO resign had an $9.8 \%$ chance of receiving a going concern audit opinion.

Logistic regression analysis was conducted on the sample firms and determined that the resignation of a CFO increases the likelihood of receiving a going concern audit opinion even after controlling for other previously documented predictors of a going concern opinion. However, no such relationship was found between a CEO resignation and a higher likelihood of a going concern audit opinion. These findings provide a necessary link 
between top management resignations and going concern opinions. Several possible explanations for this phenomenon were discussed.

Consistent with prior research, this study found that smaller firm size, negative cash flow from operations, negative one year stock return, and smaller amounts of investments increased the likelihood of receiving a going concern audit opinion.

Our paper contributes to the literature by showing that there is a positive association between CFO resignation and the receipt of going concern opinion. To our knowledge, this is the first paper to examine the association between $\mathrm{CFO}$ resignation and going concern opinion. Further studies can examine the association between CFO resignation and going concern opinion in different countries. Our study is subject to the following limitation that is inherent in this type of research. We do not investigate the potential causality issue between CFO resignation and going concern opinion due to data limitation. This limitation may draw interesting avenues for future research.

\section{References}

Beatty, R., Zajac, E. \& Chichester, J. (1987). CEO change and firm performance in large corporations: Succession effects and manager effects. Strategic Management Journal, 8(4), 305-317. http://dx.doi.org/10.1002/smj.4250080402

Beams, J., Huang, H. \& Yan, Y. (2013). Top management resignation and firms' subsequent bankruptcy. Accounting and the Public Interest, 13(1), 39-54. http://dx.doi.org/10.2308/apin-10345

Beaulieu, P. (2001). The effects of judgments of new clients' integrity upon risk judgments, audit evidence, and fees. Auditing: A Journal of Practice \& Theory, 20, 85-99. http://dx.doi.org/10.2308/aud.2001.20.2.85

Behn, B., Kaplan, S. \& Krumwiede, K. (2001). Further evidence on the auditor's going-concern report: The influence of management plans. Auditing: A Journal of Practice \& Theory, 20, 13-28. http://dx.doi.org/10.2308/aud.2001.20.1.13

Carcello, J., \& Neal, T. (2000). Audit committee composition and auditor reporting. The Accounting Review, 75, 4, 453-467. http://dx.doi.org/10.2308/accr.2000.75.4.453

Carey, P.J., Geiger, M.A., \& O'Connell, B.T. (2008). Costs associated with going-concern-modified audit opinions: An analysis of the Australian audit market. Abacus, 44(1), 61-81. http://dx.doi.org/10.1111/j.1467-6281.2007.00249.x

Chen, K., \& Church, B. (1992). Default on debt obligations and the issuance of going concern opinions. Auditing: A Journal of Practice \& Theory, 11(2), 30-49.

Chen, K., \& Church, B. (1996). Going concern opinions and the market's reaction to bankruptcy filings. The Accounting Review, 71(1), 117-128.

Dedman, E., \& Lin, S. (2002). Shareholder wealth effects of CEO departures: Evidence from the UK. Journal of Corporate Finance, 8(1), 81-104. http://dx.doi.org/10.1016/S0929-1199(01)00027-X

DeFond, M., Raghunandan, K. \& Subramanyam, K. (2002). Do non-audit fees impair auditor independence? Evidence from going concern audit opinions. Journal of Accounting Research, 40(4), 1247-1274. http://dx.doi.org/10.1111/1475-679X.00088

Desai, H., Hogan, C. \& Wilkins, M. (2006). The reputational penalty for aggressive accounting: Earnings restatements and management turnover. The Accounting Review, 81(1), 83-112. http://dx.doi.org/10.2308/accr.2006.81.1.83

Farrell, K., \& Whidbee, D. (2003). Impact of firm performance expectations on CEO turnover and replacement decisions. Journal of Accounting and Economics, 36, 165-196. http://dx.doi.org/10.1016/j.jacceco.2003.09.001

Fee, C., \& Hadlock, C. (2004). Management turnover across the corporate hierarchy. Journal of Accounting and Economics, 37(1), 3-38. http://dx.doi.org/10.1016/j.jacceco.2003.11.003

Feldmann, D., Read, W., \& Abdolmohammadi, M. (2009). Financial restatements, audit fees, and the moderating effect of CFO turnover. Auditing: A Journal of Practice \& Theory, 28(1), 205-223. http://dx.doi.org/10.2308/aud.2009.28.1.205

Feldmann, D., \& Read, W. (2010). Auditor conservatism after enron. Auditing: A Journal of Practice \& Theory, 29(1), 267-278. http://dx.doi.org/10.2308/aud.2010.29.1.267 
Geiger, M., Raghunandan, K. \& Rama, D. (2005). Recent changes in the association between bankruptcies and prior audit opinions. Auditing: A Journal of Practice \& Theory, 24, 21-35. http://dx.doi.org/10.2308/aud.2005.24.1.21

Gilson, S. (1989). Management turnover and financial distress. Journal of Financial Economics, 25(2), $241-262$. http://dx.doi.org/10.1016/0304-405X(89)90083-4

Godfrey, J., Mather, P., \& Ramsay, A. (2003). Earnings and impression management in financial reports: The case of CEO changes. Abacus, 39(1), 95-123. http://dx.doi.org/10.1111/1467-6281.00122

Kizirian, T., Mayhew, B., \& Sneathen, L. (2005). The impact of management integrity on audit planning and evidence. Auditing: A Journal of Practice \& Theory, 24(2), 49-67. http://dx.doi.org/10.2308/aud.2005.24.2.49

Knechel, R., \& Vanstraelen, A. (2007). The relationship between auditor tenure and audit quality implied by going concern opinions. Auditing: A Journal of Practice \& Theory, 26(1), 113-131. http://dx.doi.org/10.2308/aud.2007.26.1.113

Krishnan, J. (2005). Audit committee financial expertise and internal control: An empirical analysis. The Accounting Review, 80(2), 649-675. http://dx.doi.org/10.2308/accr.2005.80.2.649

Menon, K., \& Williams, D. (2008). Management turnover following auditor resignations. Contemporary Accounting Research, 25(2), 567-604. http://dx.doi.org/10.1506/car.25.2.10

Mian, S. (2001). On the choice and replacement of chief financial officers. Journal of Financial Economics, 60, 143-175. http://dx.doi.org/10.1016/S0304-405X(01)00042-3

Pourciau, S. (1993). Earnings management and nonroutine executive changes. Journal of Accounting and Economics, 16, 317-336. http://dx.doi.org/10.1016/0165-4101(93)90015-8

Zmijewski, M. (1984). Methodological issues related to the estimation of financial distress prediction models. Supplement to Journal of Accounting Research, 22, 59-82. http://dx.doi.org/10.2307/2490859 